\title{
MENINGKATKAN HASIL BELAJAR EKONOMI MENGGUNAKAN MODEL PEMBELAJARAN KOOPERATIF TIPE JIGSAW DENGAN MEDIA POWER POINT PADA KELAS X IPS-2 DI SMA NEGERI 2 KATINGAN HILIR TAHUN PELAJARAN 2016/2017
}

\author{
Oleh \\ Sinthya Ningsih ${ }^{1}$, Aidin Najihi ${ }^{2}$
}

\begin{abstract}
ABSTRAK
Penelitian ini bertujuan untuk 1) mengetahui bagaimana aktivitas belajar peserta didik dalam mengikuti pembelajaran menggunakan Model Pembelajaran Kooperatif Tipe Jigsaw dengan Power Point Media, 2) Untuk mengetahui ada tidaknya peningkatan hasil belajar ekonomi pada materi pokok pasar dan pasar harga. Setelah menggunakan model Jigsaw Type Cooperative Learning dengan Media Power Point pada siswa kelas X IPS-2 SMA Negeri 2 Katingan Hilir.

Jenis penelitian ini adalah Penelitian Tindakan Kelas (PTK). Subyek penelitian ini adalah siswa kelas X IPS-2 di SMA Negeri 2 Katingan Hilir Lesson Tahun 2016/2017 yang berjumlah 30 siswa. Analisis data digunakan dalam penelitian secara kualitatif dan kuantitatif.

Berdasarkan hasil penelitian, 1) Kegiatan pembelajaran ekonomi menggunakan model pembelajaran tipe Jigsaw dengan media power point di SMA Negeri 2 Katingan Hilir. Aktivitas peserta didik pada segmen 1 memperoleh skor rata-rata 3,18 masuk kategori menjadi baik. Sedangkan pada siklus 2 ada peningkatan menjadi lebih baik, dengan penilaian skor rata-rata 3,91 kategori baik. 2) terdapat peningkatan ekonomi hasil belajar dengan materi permasalahan materi pasar dan harga pasar dengan menggunakan model pembelajaran kooperatif tipe jigsaw dengan power point media di kelas X IPS-2 SMA Negeri Katingan Hilir tahun ajaran 2016/2017. Hal ini dapat dilihat dari hasil belajar data peserta didik pada proses pre-action moment pre test mendapatkan nilai rata-rata 61 dengan penguasaan klasik 20,00\% dengan kriteria tidak tercapai, siklus 1 mendapatkan nilai rata-rata 69,5 dengan penguasaan klasik 36,67\% dengan tidak ada kriteria yang tercapai, dan pada siklus pasca tes 2 mendapatkan nilai rata-rata 81 dengan penguasaan klasik 100\% dengan kriteria yang dicapai.
\end{abstract}

(C) Universitas Muhammadiyah Palangkaraya

Kata Kunci: Hasil Belajar Ekonomi dan Pembelajaran Kooperatif Model Jigsaw Type dan Power Point Media

\section{PENDAHULUAN}

Pendidikan memegang peranan penting dalam kemajuan dan masa depan bangsa, tanpa pendidikan yang baik mustahil suatu bangsa akan maju. Berhasil atau tidaknya suatu pendidikan dalam suatu negara salah satunya adalah karena guru. Guru mempunyai peranan yang sangat 
penting dalam perkembangan dan kemajuan anak didiknya.

Media pembelajaran terus berlangsung mengalami perkembangan seiring dengan berkembangnya dunia informasi dan teknologi. Ahmadi (2010:36) mengatakan bahwa teknologi baru terutama multimedia mempunyai peranan semakin penting dalam proses pembelajaran. banyak orang percaya bahwa multimedia akan dapat membawa kepada situasi belajar di mana dalam proses pembelajaran yang menyenangkan, kreatif, tidak membosankan akan menjadi pilihan tepat bagi para guru.

Salah satu masalah yang dihadapi dunia pendidikan di Indonesia adalah lemahnya proses belajar mengajar. Dalam proses belajar mengajar, anak kurang didorong untuk mengembangkan kemampuan berpikir. Proses pembelajaran diarahkan kepada kemampuan anak untuk menghafal informasi, otak anak dipaksa untuk mengingat dan menimbun berbagai informasi tanpa dituntut untuk memahami informasi yang di ingatnya.

Ekonomi adalah ilmu yang mempelajari tentang bagaimana

\section{METODE PENELITIAN}

Metode yang digunakan dalam penelitian ini adalah metode tindakan kelas (PTK) yang dikategorikan penelitian yang berusaha memecahkan masalah atau menjawab permasalahan yang dihadapkan pada situasi tertentu.

Arikunto (2007:3), “penelitian tindakan kelas merupakan suatu pencermatan terhadap kegiatan belajar berupa sebuah tindakan, yang sengaja manusia dan masyarakat membuat pilihan, dengan atau tanpa menggunakan uang, dalam menggunakan sumber daya produksi yang terbatas tetapi dapat dipergunakan dalam berbagai cara untuk menghasilkan berbagai jenis komoditas dari waktu ke waktu dan mendistribusikannya untuk keperluan konsumsi saat ini atau di masa datang, kepada berbagai orang atau kelompok dalam masyarakat.

Pendidikan tidak akan pernah dapat dipisahkan dengan kehidupan manusia sebagai makhluk sosial, yang berarti tidak akan mampu hidup tanpa orang lain. Pendidikan pun mempunyai tujuan yang sangat baik, salah satu tujuan pendidikan ialah membentuk manusia berkarakter. Akan tetapi, untuk meraih tujuan pendidikan secara optimal dibutuhkan beberapa faktor pendukung.

$$
\text { Parker }
$$

(Huda, 2011)

mendefinisikan peserta didik saling berinteraksi dalam kelompok-kelompok kecil untuk mengerjakan tugas akademik demi mencapai tujuan bersama.

dimunculkan dan terjadi dalam sebuah kelas secara bersama".

Dalam penelitian, kehadiran peneliti mutlak diperlukan karena kehadiran peneliti sangat diperlukan dalam setiap kegiatan di tempat penelitian. Peneliti berperan sebagai perencana, pelaksana tindakan, pengamat, reflektor dan sebagai pelapor hasil penelitian.

Penelitian ini dilaksanakan di SMA Negeri 2 Katingan Hilir pada peserta didik kelas X IPS-2 adapun subjek 
penelitiannya adalah peserta didik kelas $\mathrm{X}$ IPS-2 SMA Negeri 2 Katingan Hilir tahun pelajaran 2016/2017 yang berjumlah 30 peserta didik.

Tabel 1

Data Subjek Peneltian

\begin{tabular}{|c|c|c|}
\hline No & $\begin{array}{c}\text { Jenis } \\
\text { Kelamin } \\
\text { Peserta } \\
\text { Didik }\end{array}$ & $\begin{array}{c}\text { Jumlah } \\
\text { Peserta } \\
\text { Didik }\end{array}$ \\
\hline 1 & Laki-laki & 16 Orang \\
\hline 2 & Perempuan & 14 Orang \\
\hline \multicolumn{2}{|c|}{ Jumlah } & 30 Orang \\
\hline
\end{tabular}

\section{HASIL DAN PEMBAHASAN}

Pada tahap ini peneliti melaksanakan tindakan pembelajaran model pembelajaran kooperatif tipe jigsaw dengan media power point.

1. Peningkatan Aktivitas Peserta

Didik Siklus I dan Siklus II

Tabel 2

Peningkatan Aktivitas Peserta Didik Siklus I Dan Siklus II

\begin{tabular}{|l|c|c|}
\hline Pelaksanaan & $\begin{array}{c}\text { Skor } \\
\text { Total }\end{array}$ & Rata-Rata \\
\hline Siklus I & 35 & 3,18 \\
\hline Siklus II & 43 & 3,91 \\
\hline
\end{tabular}

Grafik 1

Peningkatan Aktivitas Peserta Didik

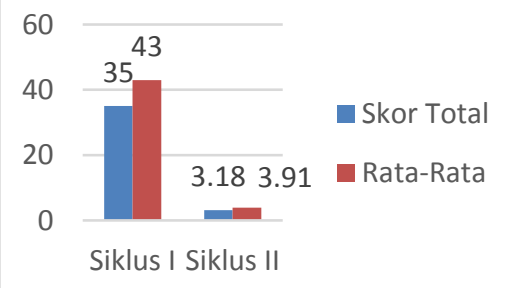

Berdasarkan tabel dan grafikmpada gambar diatas dapat menunjukan peningkatan aktivitas belajar peserta didik yang signifikan dari siklus I rata-rata 3,73 dengan kriteria Baik dan
(Sumber Data : Daftar Hadir Guru Mata Pelajaran Ekonomi Kelas X IPS-2 )

Data yang dikumpulkan dari setiap kegiatan yang dilaksanakan dalam siklus PTK dianalisis secara deskriptif dengan menggunakan teknik presentasi untuk melihat kecenderungan yang terjadi dalam pembelajaran data yang diperoleh melalui instrumen yang telah dikumpulkan sebelumnya diolah menjadi dua jenis data yaitu jenis data kualitatif dan kuantitatif tentang hasil belajar

siklus II rata-rata 3,82 dengan kriteria Baik. Dengan demikian peningkatan ketuntasan aktivitas belajar Ekonomi peserta didik dengan menggunakan media power point pada peserta didik kelas X IPS-2 SMA Negeri 2 Katingan Hilir dapat dikatakan berhasil.

Hasil observasi oleh dua orang observer terhadap pengolahan pembelajaran pada mata pelajaran Ekonomi pada materi pokok bahasan masalah pasar, fungsi pasar dan ciri-ciri pasar serta masalah harga pasar dengan menggunakan media power point, saat pembelajaran berlangsung dinilai oleh dua orang observer yaitu guru dan teman sejawat, hasil observasi tersebut dapat diuraikan secara rinci pada tabel sebagai berikut:

Tabel 4

Rekapitulasi Hasil Observasi Aktivitas Guru dan Peserta Didik

\begin{tabular}{|c|c|c|c|c|}
\hline \multirow{3}{*}{ Aktivitas } & \multicolumn{4}{|c|}{ Nilai Rata-Rata } \\
\hline & \multicolumn{2}{|c|}{$\begin{array}{c}\text { Guru Mata Pelajaran } \\
\text { Ekonomi } \\
\text { (Pengamat 1) }\end{array}$} & \multicolumn{2}{|c|}{$\begin{array}{c}\text { Teman Sejawat } \\
\text { (Pengamat 2) }\end{array}$} \\
\hline & Siklus I & Siklus II & Siklus I & Siklus II \\
\hline Guru & 3,31 & 3,85 & 3,31 & 3,85 \\
\hline \begin{tabular}{|l} 
Peserta \\
Didik
\end{tabular} & 3,18 & 3,91 & 3,18 & 3,91 \\
\hline
\end{tabular}


2. Hasil Belajar Peserta Didik dengan Menggunakan Media Power Point

Tabel 3

Hasil Belajar Peserta didik Pada Pra Tindakan dan Post Tes

\begin{tabular}{|c|c|}
\hline Pelaksanaan & $\begin{array}{c}\text { Hasil } \\
\text { Belajar }\end{array}$ \\
\hline Pra Tindakan (Pre Test) & $20,00 \%$ \\
\hline Siklus I (Post Tes) & $134 \%$ \\
\hline Siklus II (Post Test) & $100 \%$ \\
\hline
\end{tabular}

\section{Grafik 2}

Peningkatan Hasil Belajar

Peserta Didik pada Pra tindakan, Siklus I, dan Siklus II

\begin{tabular}{|c|c|c|c|}
\hline $150.00 \%$ & \multicolumn{3}{|c|}{$134 \%$} \\
\hline \multicolumn{4}{|l|}{$100.00 \%$} \\
\hline $50.00 \%$ & $20.00 \%$ & & \\
\hline \multirow[t]{2}{*}{$0.00 \%$} & & & \\
\hline & $\begin{array}{c}\text { Pra } \\
\text { Tindakan } \\
\text { (Pre Test) }\end{array}$ & $\begin{array}{c}\text { Siklus I } \\
\text { (Post Tes) }\end{array}$ & $\begin{array}{c}\text { Siklus II } \\
\text { (Post Test) }\end{array}$ \\
\hline
\end{tabular}

\section{SIMPULAN}

Berdasarkan hasil penelitian yang dilakukan oleh peneliti dapat disimpulkan bahwa melalui penerapan model pembelajaran kooperatif tipe Jigsaw dengan media Power Point yaitu:

1. Aktivitas Pembelajaran Ekonomi dengan menggunakan model pembelajaran tipe Jigsaw dengan media Power Point pada SMA Negeri 2 Katingan Hilir. Aktivitas peserta didik pada siklus I memperoleh skor rata-rata 3,18 masuk kategori menjadi baik. Sedangkan pada siklus II ada peningkatan menjadi lebih baik, dengan penilaian skor rata-rata 3,91 kategori baik.
Berdasarkan hasil pada gambar tabel dan grafik di atas, maka dapat diketahui bahwa hasil perolehan nilai peserta didik pada saat pra tindakan sampai pada post test siklus I dan siklus II mengalami adanya peningkatan yaitu, pada proses pra tindakan hasil pre test sebesar $20,00 \%$, post test siklus I sebesar $134 \%$, akan tetapi belum memenuhi hasil belajar secara klasikal, dan pada saat post test siklus II peserta didik menunjukan adanya peningkatan dengan memperoleh ketuntasan klasikal sebesar 100\%. Hal ini dapat menunjukan bahwa dengan menggunakan media power point dapat meningkatkan hasil belajar peserta didik pada mata pelajaran Ekonomi dengan materi pokok bahasan masalah pasar, fungsi pasar dan ciri-ciri pasar serta masalah harga pasar pada setiap siklusnya.

2. Ada peningkatan hasil belajar Ekonomi dengan materi pokok bahasan masalah pasar dan harga pasar dengan menggunakan model pembelajaran Kooperatif tipe Jigsaw dengan media Power Point pada kelas X IPS-2 di sekolah SMA Negeri 2 Katingan Hilir Tahun Pelajaran 2016/2017. Hal ini dapat dilihat dari data hasil belajar peserta didik pada proses pra tindakan saat Pre Test memperoleh nilai rata-rata 61 dengan ketuntasan klasikal 20,00\% dengan kriteria Tidak Tercapai, Siklus I memperoleh nilai rata-rata 69,5 dengan ketuntasan klasikal 36,67\% dengan kriteria Tidak Tercapai, dan pada Post Test siklus II memperoleh 
BITNET Jurnal Pendidikan Teknologi Informasi, Februari 2019, Volume 4 Nomor 1 (20-24) http://journal.umpalangkaraya.ac.id/index.php/bitnet

$\begin{array}{lllll}\text { nilai } & \text { rata-rata } & 81 & \text { dengan } & \text { kriteria Tercapai. } \\ \text { ketuntasan } & \text { klasikal } & 100 \% & \text { dengan } & \end{array}$

DAFTAR PUSTAKA

Ahmadi, Lif Khoiru. 2010.Strategi Pembelajaran Sekolah

Alfabeta. Arikunto. S,dkk. 2007. Penelitian Tindakan Kelas. Berstandar Internasional dan
Nasional. Jakarta: PT Pustaka Raya.

Huda, M.(2011). Cooperatif Learning Metode, Teknik, Struktur dan Model Penerapan. 